\title{
DIAGNOSTIC METHODS FOR CANINE PARVOVIRUS
}

\author{
SAVIĆ-JEVĐENIĆ SARA*, TRAILOVIĆ D**, VIDIĆ BRANKA*, JOVANOVIĆ M** \\ * Scientific Veterinary Institute "Novi Sad", Novi Sad \\ ${ }^{\star \star}$ Faculty of Veterinary Medicine, Belgrade \\ (Received 17. April 2006)
}

The aim of this study was to investigate the efficacy of different laboratory methods for diagnosing parvovirus infection in dogs. Experimental infection was induced in 12 puppies. After the onset of manifest disease symptoms, the dogs were subjected to daily clinical observation, and virus detection was performed using immunochromatography and haemmaglutination test, while immunofluorescence was applied for the detetion of the virus within the intestinal epithelium. The clinical form of the parvovirus infection was provoked in all dogs that were in contact with sick animals, and all affected animals died. Symptoms observed in affected dogs included apathy, appetite loss, vomiting, dehydration and profuse, haemorrhagic diarrhoea. Immunochromatography and haemagglutination confirmed the presence of the virus in the faeces one day after manifestation of clinical symptoms in $100 \%$ of the affected dogs. On day 2 the virus was detected in $85 \%$ and $53 \%$ of the sick animals by the methods of haemagglutination and immunochromatography, respectively. Before death, the virus was detected by haemagglutination and immunochromatography in $61 \%$ and $15 \%$ dogs, respectively. Immunofluorescence assay revealed the presence of the virus in tissue samples of small intestines in all infected animals.

Key words: canine parvovirus, enteritis, diagnostic methods

\section{INTRODUCTION}

Canine parvovirus Type 2 (CPV-2) is one of the most frequent causative agents of acute haemorrhagic enteritis in dogs. By it's antigenic and genetic structure CPV-2 resembles other carnivorous parvoviridae, such as feline panleucopenia virus (FPLV), mink enteritis virus (MEV), raccoon parvovirus (RPV), blue fox parvovirus (BFPV) etc., which are classified in the canine parovoviridae subgroup of the genus Parvovirus, family Parvoviridae (Kuffer et al., 1997; Desario et al., 2005). CPV contains a DNA genome surrounded by a protective protein coat. The virion is a non-enveloped particle characterized by icosahedral morphology, about $22 \mathrm{~nm}$ in diameter. The virion is composed of three structural 
viral proteins (VPs) labelled as VP1, VP2 and VP2' (Mochizuki et al., 1993; Carmichael et al., 1996).

CPV was first described in association with clinical enteritis in dogs. Viral infection rapidly spread all over the world, and today is considered to be a frequent causative agent of the disease in dogs. The virus is associated with haemorrhagic enteritis and miocarditis, primarily in puppies and young dogs (O'Sullivan et al.,1984; Trailović, 1999). The way of infection is via the oronasal route. Three to ten days after onset of symptoms such are vomiting, elevated body temperature and diarrhoea rapid dehydration develops. The virus is shed in the faeces during several days. Considering the high resistance of the virus in the environment, its infective potential may persist in the faeces over a long period of time, sometimes for years (Houston, 1996). In kennels which exhibit parovovirus outbreaks the infective agent may persist permanently in the buildings, outside pens and excersize areas. In such kennels there is a persistent danger of infection outbreaks in puppies, despite vaccination regime or particularly carefull personnel. Puppies between the ages of 6 to 12 weeks are at the highest risk of parvovirus infection, due to loss of maternal immunity. The main source of infection are infected dogs. Clinical diagnosis by itself is not reliable enough, and laboratory examination is recommended. Etiological diagnosis can be established with a high degree of certainty by methods like haemagglutination, immunofluorescence, immunochromatography tests and detection of specific antibodies, ELISA (Mochizuki et al., 1993; Senekata et al., 1996; Esfandiari and Klingeborn, 2000).

With the aim of investigating the efficacy of particular laboratory assays for the detection of parvovirus infection we set forth several tasks, such as to investigate possibilities of virus detection in the faeces of dogs with parvovirus enteritis; to compare the validity of the investigated laboratory methods for diagnosing parvovirus infection in dogs, i.e. haemagglutination, immunofluorescence test and rapid tests based on immunochromatography methods, as well as to suggest the most accurate and reliable laboratory methods for diagnosing canine parvovirus infection, and to establish criteria for diagnosis in field conditions

\section{MATERIAL AND METHODS}

\section{Experimental animals}

Material: The experimental animals were 19 half breed dogs of both genders ( 10 male and 9 female) were used. The dogs were 2 to 3 months old. The puppies originated from non-vaccinated, seronegative bitches whelped under controlled conditions and without contact with other dogs. Until the beginning of the experiment the puppies were neither in contact with other dogs, nor were vaccinated against any disease. The puppies were marked and observed daily throughout the investigation period. The puppies were distributed in two groups: the experimental and the control group consisting of 13 and 6 puppies, respectively. The puppies from the same group were housed in the same box, and 
received food and water in the same feeders. The puppies were fed agebalanced, pelleted food, twice a day, according to producer's guidelines.

Prior to be included in the experiment the puppies were quarantined for 10 days, and subject to thorough clinical observation and dehelminthization. Before the beginning of the experiment faeces samples were taken from each puppy and assayed for the presence of parvovirus by haemagglutination and immunochromatography tests. During the experiment the same feeding regimen was applied until the onset of clinical symptoms. Water was given ad libitum.

Infection: After a ten-day quarantine the puppies (ageed from 2.5 to 3.5 months) were exposed and in contact with a sick puppy of the same age, which exhibited typical disease symptoms, and in which the disease was confirmed. Since the first contact with the diseased animal the puppies were observed daily, all clinical symptoms recorded and body temperature measured. Faecal samples and rectal swabs were taken daily. All collected samples were distributed in three groups:

I - samples collected on day 1 after onset of clinical symptoms,

II - samples collected on day 2 after onset of clinical symptoms,

III - samples collected just before the death.

After the puppies died, post-mortem examination was performed and samples were collected for the immunofluorescence reaction.

\section{Methods}

Clinical examination: The dogs were observed daily. Along with blood and faeces sampling, body temperature was measured and common clinical examination was performed including palpation, adspection and auscultation. All findings were recorded in the data sheet. Irrespective of the manifested clinical symptoms, all dogs were examined daily. After the onset of clinical symptoms, the examination was performed three times a day.

Immunochromatography test: The test was performed during ten-day quarantine and on days 1 (I) and 2 (II) after the onset of clinical symptoms, as well as one day before or on the day of death (III). The test was performed according to the producer's instruction, Civtest Parvocan-AG "one step".

Haemagglutination test was performed on faecal samples collected by rectal swabs. In the reaction $1 \%$ pig erythrocytes and PBS pH 7.2 as solvent were used. The reaction was conducted in microplates. Faecal samples were dissolved in PBS $\mathrm{pH}$ 7.2. The reaction was read after 4 hours of incubation at $4^{\circ} \mathrm{C}$.

After autopsy, changes characteristic for canine parvovirus enteritis were recorded i.e. the appearance of the small intestine and the content of the small intestine.

To the purpose of pathohistologic examination sections of the intestinal tissue were prepared and stored at $-20^{\circ} \mathrm{C}$ until examination. The reaction was performed according to producer's instruction, using a conjugate (canine parvovirus, LOT\# 981103CPV). The results were evaluated by fluorescence microscopy.

Pathomorphological examination was performed applying common procedures following staining small intestine sections with haematoxylin eosin. 


\section{RESULTS}

Clinical symptoms in all studied cases occurred suddenly, being clearly pronounced and indisputable. The occurrence of clinical symptoms by days is summarized in Table 1.

Table 1. Number of dogs with clinical symptoms / day since the infection

\begin{tabular}{|l|c|c|c|c|}
\hline $\begin{array}{c}\text { Days since contact with } \\
\text { the infected dog }\end{array}$ & 1. day & 2. day & 3. day & 4. day \\
\hline \hline Number of sick dogs & 0 & 2 & 6 & 5 \\
\hline$\%$ of sick dogs & 0 & 16 & 46 & 38 \\
\hline
\end{tabular}

Similar clinical symptoms were observed in all puppies (Table 2). On the first day all affecte dpuppies exhibited similar behaviour. The dogs were sleepy, depressed, lacking appetite, hiding in corners of the room and avoiding contact with other dogs. Body temperature was elevated, ranging from $39,8^{\circ} \mathrm{C}$ to $40,5^{\circ} \mathrm{C}$. On the next day (sometimes even after several hours) meagreness and dehydration were observed, followed by frequent vomiting. Sometimes the puppy only showed the impulse to vomit, but lacking any stomach content.

Table 2. Clinical symptoms in experimantal dogs

\begin{tabular}{|c|c|c|c|c|c|c|c|c|}
\hline \multirow{2}{*}{$\begin{array}{l}\text { Dog } \\
\text { mark }\end{array}$} & \multicolumn{8}{|c|}{ Apearance of first clinical symptoms in days } \\
\hline & 1. & 2. & 3. & 4. & 5. & 6. & 7. & 8. \\
\hline 1 & TA A & TAHDE & & & & & & \\
\hline 2 & $\mathrm{TAVD}$ & TAHDE & & & & & & \\
\hline 3 & TA & A V HD & A HD E & & & & & \\
\hline 4 & $\mathrm{TA}$ & $A \vee D$ & A HD & A HD E & & & & \\
\hline 5 & $\mathrm{TAV}$ & TAVHDE & & & & & & \\
\hline 6 & $\mathrm{TAV}$ & TA HD & A HDE & & & & & \\
\hline 7 & $\mathrm{TA}$ & TAHD & A HD E & & & & & \\
\hline 8 & $\mathrm{TA}$ & $\mathrm{TAV}$ & $A \vee D$ & A HD E & & & & \\
\hline 9 & $\mathrm{TA}$ & $\mathrm{TAVD}$ & $\mathrm{AVHDE}$ & & & & & \\
\hline 10 & $\mathrm{TA}$ & $\mathrm{TAVD}$ & TAVD & A HD & A HD & A HD & A HD & A HD E \\
\hline 11 & $A$ & TAVD & $A H D$ & A HD E & & & & \\
\hline 12 & $\mathrm{TA}$ & $A \vee H D$ & $\mathrm{~A} \vee \mathrm{HD}$ & A HD E & & & & \\
\hline 13 & $\mathrm{TA}$ & $\mathrm{TAVHD}$ & $\mathrm{AHD}$ & A HD E & & & & \\
\hline$\sum \mathrm{E}$ & - & $23 \%$ & $31 \%$ & $38 \%$ & & & & $8 \%$ \\
\hline
\end{tabular}

T - high body temperature; D - diarrhea; A - apathy; HD bloody stool; V - vomitus; E - exitus

The vomited content was at first pasty, turning to slimy, and at last watery (saliva-like), grey-yellowish in colour. The dogs tried to reach water, with a lot of effort. The stomach was extremely retracted, reflecting the painfulness of the abdomen. Even if they reached the water - bowl, the animals unsuccessfully tried 
to drink, immediately giving up after the first lick. The body temperature ranged from 39,0 to $39,8^{\circ} \mathrm{C}$. Three puppies died during this stage of the disease, i.e. only two days after onset of clinical symptoms. On day 3 after the onset of clinical symptoms, the "meagreness" was even more pronounced, progressing to cachexia. The puppies could hardly stand up, and diarrhoea commenced. In some puppies the diarrhoea may be observed even one day earlier, but it was always preceded by several hours of vomiting. The diarrhoeal discharge is profuse, dark yellow or brown to brown-grey, and pasty. Later on it turns brownred, and in some puppies it becomes dark red, like blood. The first stools reveal some food remainings, changing with time to a liquid discharge characterized by an offensive, foul odour to musty blood and rot. The animal completely rejects food and water. The abdominal pain is clearly evident. When taking the puppies they screech, but they are not capable to scramble due to their weakness. The intestines are empty, and peristalsis accelerated (weak murmur). The mucosa is pale, and after touching it hardly visible pink colour is slowly recovered at the site of palpation. The hair is dull, dry, sometimes bristled; eye bulbs are hollow (signs of dehydration). Puppies in this condition died quietly, without barking or yelping. Such condition persisted for several days in some animals, and one puppy survived even 8 days exhibiting an absolutely unchanged clinical picture every day. Body temperature gradually decreased, reaching $35,7-37,9^{\circ} \mathrm{C}$ before death.

In dogs from the experimental group the highest mortality rate was observed on day 4 after the onset of clinical symptoms (38\%), on day $3(31 \%)$, and on day $2(23 \%)$. Only one puppy (8\%) survived 8 days after onset of clinical symptoms. Death is the consequence of excessive loss of water and electrolytes, as well as development of metabolic acidosis and endotoxaemia (Otto et al., 1997).

In the control group no clinical symptoms were observed throughout the entire investigation period.

Results obtained by the immunochromatography test kits are evaluated either as positive (+) or negative (-). Faeces analyses performed during 10-day quarantine period (before infection) revealed negative findings. With an immunochromatography test parvovirus was detected on the first day in all dogs (100\%) with characteristic clinical symptoms (Fig. 1). On day 2 the virus was not anymore detectable in six dogs, positive finding was observed in seven dogs (53\%), and all dogs have been exhibiting symptoms characteristic for parvovirus infection. One day before or on the day of death parvovirus was detected in the faeces samples of only two dogs (15\%). Faecal samples obtained from the control group revealed negative results.

Haemagglutination results of faeces analyses (Fig. 1.) are evaluated as positive $(+)$ or negative $(-)$, and titer values were determined in positive samples. Faeces analyses performed during the 10 -day quarantine revealed $100 \%$ negative findings, hence not displayed in a separate figure. Haemagglutination reaction on day 1 revealed the presence of the virus in all sick dogs (100\%) with titer values ranging from 1:32 to 1:2048 (Table 3). On day 2 after the onset of clinical symptoms a decrease of titer values was observed in faecal samples of all dogs, except for one, being 1:2048. Titer values on day 2 ranged between 1:8 and 


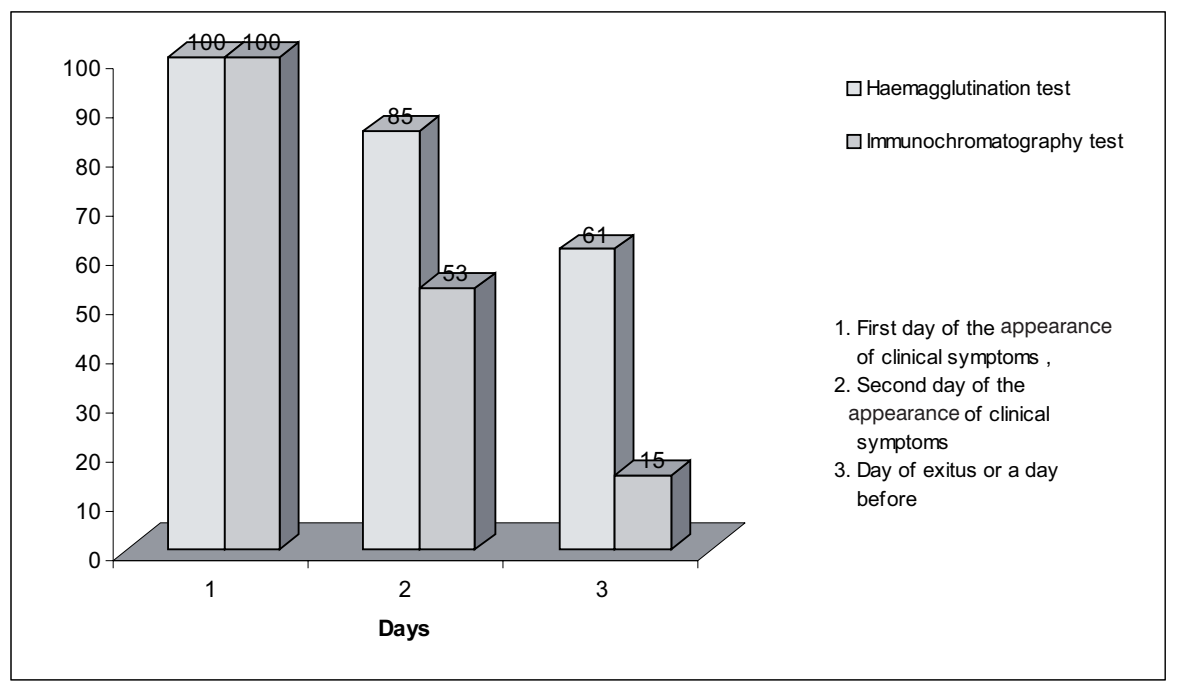

Figure 1. Presence of canine parvovirus in faecal samples of experimental dogs by immunochromatography and haemagglutination test

Table 3 Results of haemagglutination test in diagnostic of canine parvovirosis in experimental dogs

\begin{tabular}{|c|c|c|c|c|c|c|}
\hline \multirow{2}{*}{ Dog mark } & \multicolumn{3}{|c|}{1.} & \multicolumn{2}{c|}{2.} & \multicolumn{2}{c|}{3.} \\
\cline { 2 - 7 } & \multicolumn{2}{|c|}{ Titre } & \multicolumn{2}{c|}{ Titre } & \multicolumn{2}{c|}{ Titre } \\
\hline \hline 1 & + & $1: 128$ & + & 32 & - & - \\
\hline 2 & + & $1: 128$ & + & $1: 64$ & + & $1: 16$ \\
\hline 3 & + & $1: 2048$ & + & $1: 2048$ & + & $1: 1024$ \\
\hline 4 & + & $1: 128$ & + & $1: 64$ & - & - \\
\hline 5 & + & $1: 2048$ & + & $1: 16$ & + & $1: 8$ \\
\hline 6 & + & $1: 1024$ & + & $1: 8$ & + & $1: 4$ \\
\hline 7 & + & $1: 64$ & - & - & - & - \\
\hline 8 & + & $1: 2048$ & + & $1: 128$ & + & $1: 64$ \\
\hline 9 & + & $1: 256$ & + & $1: 8$ & + & $1: 2$ \\
\hline 11 & + & $1: 32$ & + & $1: 32$ & - & - \\
\hline 11 & + & $1: 128$ & + & $1: 16$ & + & $1: 8$ \\
\hline 12 & + & $1: 32$ & - & - & - & - \\
\hline 13 & + & $1: 64$ & + & $1: 8$ & + & $1: 4$ \\
\hline $1 \mathrm{~K}-6 \mathrm{~K}$ & - & - & - & - & - & - \\
\hline
\end{tabular}

First day of the appearance of clinical symptoms (1.), Second day of the appearance of clinical symptoms (2.) Day of exitus or a day before (3.) 
Acta Veterinaria (Beograd), Vol. 56. No. 5-6, 515-527, 2006.

Savić-Jevđenić Sara et al.: Diagnostic methods

for canine parvovirus

$1: 2048$, the haemagglutination reaction was positive in $11(85 \%)$ dogs, and in two dogs titer values were at an undetectable level, meaning that the haemagglutination reaction was negative. Before death haemagglutination reaction was still positive in $8(61 \%)$ dogs with titer values ranging from $1: 2$ to $1: 1024$. In all dogs the determined values were lower in comparison to the previous sampling. Faecal samples obtained from 5 dogs by the third sampling procedure proved negative, i.e. the virus was not detected. Haemagglutination reaction revealed a $100 \%$ negative result in the control group.

All dogs from the experimental group died (Table 4). Post mortem examination of each puppy was performed, revealing findings that were closely similar for all investigated animals, corresponding to the changes characteristic for canine parvovirosis.

Table 4. Number of perished dogs in days from the apperiance of first clinical symptoms

\begin{tabular}{|l|c|c|c|c|c|}
\hline $\begin{array}{l}\text { Days from the apperiance } \\
\text { of first clinical symptoms }\end{array}$ & 1. day & 2. day & 3. day & 4. day & 8. day \\
\hline \hline Number of perished dogs & 0 & 3 & 4 & 5 & 1 \\
\hline$\%$ of perished dogs & 0 & 23 & 31 & 38 & 8 \\
\hline
\end{tabular}

The cadavers were dehydrated, the hair dull and flattened. The anal canal was contaminated with the malodorous excrement. Hairs in the mouth region were sticky, eye pits without discharge, but hollow. The tonsillae and thymus were enlarged in 5 and 2 dogs, respectively. Peritoneal cavity was without any content, the adipose tissue white. No massive changes were observed in any internal organs, except for the gastrointestinal tract. The spleen was dark red to livid, pasty and with rugged margins. The liver brittle, with rugged margins. When pressing the liver cross-section, the fingers easily penetrated the tissue. The gallbladder was filled with dark yellow or brown bile content. The stomach was mainly empty, with more or less milky-white to crystal yellow, slimy content. The serous membranes were white to grey-yellow in colour. The mucous membranes were grey, extremely rugged. In 4 puppies spotted diffuse bleedings were observed. Mesenterium was characterized by highly initiated blood vessels (Fig. 2). Thes serosa of the small intestine was light or dark grey, somewhere livid, with initiated blood vessels and haemorrhages in all puppies. The content of the small intestine was liquid, particularly malodorous, brown

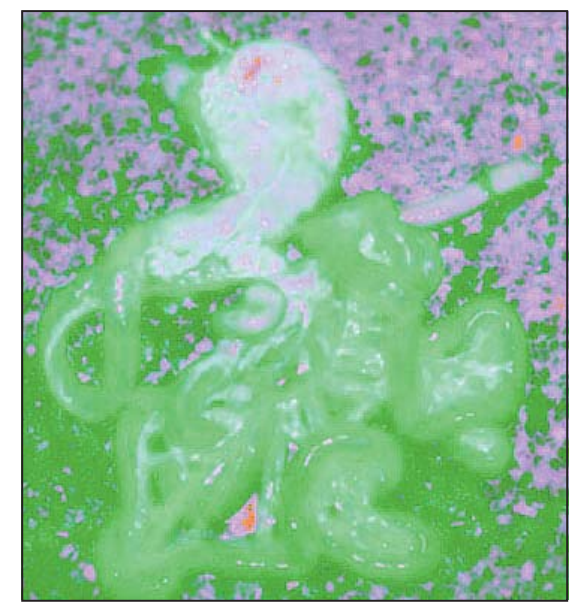

Figure 2. The characteristic appearance of the small intestine in a dog infected with caninne parvovirus 
to dark red in colour because of blood content. Mucous membranes were callous, covered with bleedings. The serosa of the large intestine was grey-brown in colour, and the mucous membrane was callous with pronounced brindle-like haemorrhages in 9 dogs (Fig. 3). The content of the large intestines was completely bloody. The kidney capsule easily detached, and the blood vessels weakly initiated. At the cross-section the cortex clearly differentiated from the medulla. The bladder was mostly filled with content. The chest cavity was without visible changes. The findings on the small and large intestines are pathognomonic for parvovirus infection.

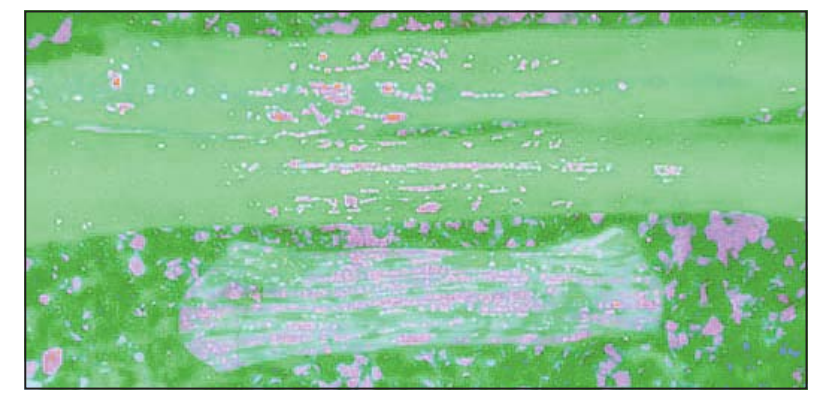

Figure 3. The content and the appearance of the small and large intestine mucosa in a dog infected with caninne parvovirus

Results of the examination of small intestines by the immunofluorescence method revealed to be positive, i.e. proved the presence of canine parvovirus in all 13 investigated animals.

Examination of small intestine samples after staining with haematoxylin and eosin revealed characteristic changes in the lymphoid tissue, Peyer's patches and small intestine epithelium. The most typical changes were observed in the region of the villi and crypts. The changes were manifested as acute necrosis of the epithelium. Intestinal villi were shortened, even completely flattened, which is due to massive injuries. The crypts were collapsed or dilated, filled with cellular detritus. Necroses may be found in the lymphoid follicles of the Peyer's patches. In the submucosa the dilated blood vessels were visible as well as distinct bleedings. Specific basophilic inclusions were observed in the epithelial cells of the intestines (Fig. 5). In experimentally infected dogs the first histological changes (shortening of the intestinal villi) were detectable 4 days after infection. After 6 days undergrowth of the duodenal and jejunal villi was noted, associated with the occurrence of vacuoles in the apical epithelial cells of the villi, which is due to the cell ageing and lack of the newly-formed, young cells. Shortening and attenuation of the intestinal villi occurred simultaneously with the onset of first clinical symptoms.

Results of virus detection in faecal samples on the day of death, using immunochromatography test, haemagglutination and immunofluorescence methods are summarized in Table 6 . It is obvious that on the day of death the 
Acta Veterinaria (Beograd), Vol. 56. No. 5-6, 515-527, 2006.

Savić-Jevđenić Sara et al.: Diagnostic methods

for canine parvovirus

parvovirus was isolated in all affected animals by the of immunofluorescence method.

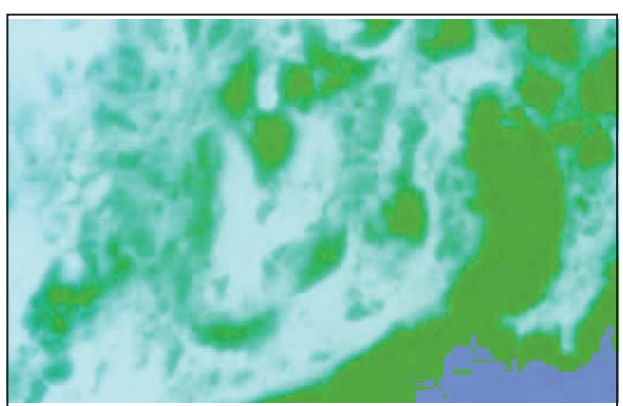

Figure 4. Immunoflorescence test of the small intestine in a dog infected with canine parvovirus

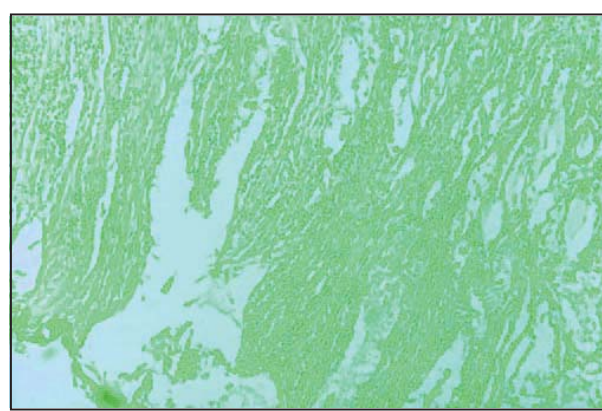

Figure 5. Hystopathological finding of the small intestine in a dog infected with caninne parvovirus

Tabela 6. Comparison of the results of immunochromatography, hemagglutination and immunofluorescence test in diagnostic of canine parvovirosis in experimental dogs

\begin{tabular}{|c|c|c|c|}
\hline Dog mark & Immunochr. & Haemagglut. & Imunofluoresc. \\
\hline \hline 1 & - & - & + \\
\hline 2 & + & $1: 16$ & + \\
\hline 3 & + & $1: 1024$ & + \\
\hline 4 & - & - & + \\
\hline 5 & - & $1: 8$ & + \\
\hline 6 & - & $1: 4$ & + \\
\hline 7 & - & - & + \\
\hline 8 & - & $1: 64$ & + \\
\hline 9 & - & $1: 2$ & + \\
\hline 10 & - & - & + \\
\hline 11 & - & $1: 8$ & + \\
\hline 12 & - & - & + \\
\hline 13 & - & $1: 4$ & 100 \\
\hline$\sum$ in $\%$ & 15 & 61 & \\
\hline
\end{tabular}

\section{DISCUSSION}

The incubation period, after contact with manifestly sick dog, was 2 - 4 days. The majority of the dogs got sick on day 3 after the contact, i.e. all dogs that were in contact with the manifestly sick dog got sick. This implies a particularly high morbidity rate $(100 \%)$, which corresponds to the available references (Carman and Povey, 1980; Carmichael, 1996; Oana et al., 2000). 
All recorded clinical symptoms are characteristic for the usual clinical frame of the enteral form of parvovirus infection in dogs (O'Sullivan et al., 1984; Trailović, 1999). The appearance and course of the clinical symptoms corresponds with literature data (Macartney et al., 1984; Carmichael, 1996), emphasizing the relatively short course of the disease in all investigated animals, which is obviously due to high virulence of the virus and high susceptibility to infection of the puppies. All sick puppies died relatively quickly, within 2-4 days, with pronounced dehydration caused by massive loss of water and electrolytes, and with likely impairment of the acidobasic balance. Only one puppy survived until day 8 after infection.

Loss of water and electrolytes is the consequence of the persistent, profuse, bloody diarrhoea associated with the decreased absorption capacity of the intestinal epithelium (Oana et al., 2000). Manifest apathy and depression are mostly the result of metabolic acidosis induced by bicarbonate loss. Hypovolemic shock is the final and most severe stage of this clinical picture. All diseased dogs died, indicating the particularly high mortality rate (100\%). There are reports on mortality rates of $10 \%$ in treated dogs, reaching $25-30 \%$ in other cases (Carmichael, 1996; Kuffer et al., 1997). Since all puppies suffered a lethal outcome of the disease, the observed clinical symptoms are to be considered unfavourable prognostic signs, particularly in the case of vomiting, haemorrhagic diarrhoea and pronounced dehydration that lasts for several days.

Immunochromatography test is simple to use and rapid, and results are available in 10 to 15 minutes. In all dogs with obvious clinical symptoms the presence of the virus in all the investigated samples was confirmed in the first sampling. The presence of the virus in the faeces was confirmed by the method of immunochromatography during the first days of infection, i.e. only in the period of faecal virus excretion. Moreover, we may conclude that the amount of excreted virus is of the most importance to be detectable by the immunochromatography test. Thus a negative test result cannot necessarily exclude the parvovirus infection in a dog, but indicates that the virus is not any longer excreted in the faeces or is excreted in unsubstantial amounts.

The haemagglutination method confirmed parvovirus infection in all dogs in the first sampling and before death (61\%). Titer values are not of prognostic significance, considering the final outcome, i.e. the dogs, in which the virus could not be detected any more before death, have died anyway. The method may be evaluated as more sensitive then the immunochromatography test considering the higher rate of positive findings in the III sampling. However, some references indicate that, apart from CPV, some other enteropathogenic organisms may induce the haemagglutination reaction, resulting in a false positive finding (Mochizuki et al., 1993; Drane et al., 1994).

The method of direct immunofluorescence can be performed only in a wellequipped pathohistologic laboratory. Preparation of the sections requires several days, making the procedure time consuming. It is necessary to take samples of the small intestine during autopsy. The reaction is highly specific, employing the specific parvovirus conjugate. The method is sensitive enough, thanks to a direct 
detection of the virus in the intestinal villi or tissue remainings. Thus, detection is possible even after cessation of viral excretion in the faeces.

Comparison of the three reactions: Civtest Parvocan-Ag test, haemagglutination reaction and immunofluorescence revealed that immunofluorescence reaction proved highly sensitive and specific, being however most time consuming and demanding with respect to laboratory equipment and conditions. Moreover, this method is applicable only for post mortem diagnosis (Esfandiari and Klingeborn, 2000).

Application of Parvocan test enables results on the same day, and in our investigation it proved acceptable for early detection of the virus in the initial stage of the infection. Haemagglutination method is recommended for the confirmation of parvovirus infection in dogs with clinical symptoms. It proved applicable also in the case of negative Parvocan-test results, when dogs exhibit symptoms characteristic for canine parvovirus infection. Haemagglutination reaction and Civtest Parvocan-Ag tests are not of distinguished prognostic value, they can only provide accurate diagnosis by confirming the presence of the virus in faecal samples. Depending on the prognosis, the patient may be subjected to further laboratory analysis (if the diagnosis is still doubtful), like faeces analysis by the haemagglutination reaction. In dead animals, suspected for parvovirus infection, the accurate confirmation of the diagnosis is obtained in the laboratory, by the immunofluorescence and by pathomorphological examination.

In accordance with the performed analyses and the obtained results, as well as after comparing different diagnostic methods for detection of canine parvovirus infection, we may conclude as following:

1. Direct exposure of non-vaccinated puppies originating from nonvaccinated bitches to the puppy affected with parvovirus infection results in the occurrence of the same disease in the puppies from the experimental group, the morbidity rate being $100 \%$. All affected puppies died, hence a $100 \%$ mortality rate was determined.

2. Parvovirus is detectable in the faeces of dogs affected by parvovirus infection by the use of rapid tests, such as Civtest Parvocan-Ag "one step" and haemagglutination reaction.

3. At the initial stage of the disease an accurate parvovirus diagnosis can be made by faeces analysis using Parvocan tests, while in the advanced stage the haemagglutination reaction proved to be more effective and accurate. Immunofluorescence is the most reliable method for diagnosing parvovirus infection, providing positive post mortem result in dogs affected by parvovirus infection, irrespectable of the duration of the disease.

4. Rapid tests are applicable as reliable and effective diagnostic methods at the initial stage of the disease, while more complex cases require haemagglutination reaction and immunofluorescence method.

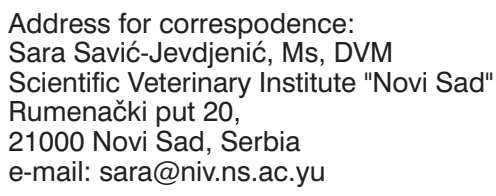




\title{
REFERENCES
}

1. Carman PS, Povey $R C, 1980$, Experimental challenge of dogs with canine parvovirus-2, Vet $R e c, 8$, 447.

2. Carmichael $L E, 1996$, Canine parvovirus type 2 infection and neonatal and in utero infections caused by canine herpes virus and the minute virus of canines, Proceedings and abstracts, XXIst Congress of the WSAVA, Jerusalem, 252-8.

3. Desario C, Decaro N, Campolo M, Cavalli Aleksandra, Cirone F, Elia Gabriella, Martella V, Lorusso Eleonora, Camero Michele, Buonevoglia C, 2005, Canine parvovirus infection:Which diagnostic test for virus?, J Vir Meth, 126, 179-85.

4. Drane DP, Hamilton RC, Cox JC, 1994, Evaluation of a novel diagnostic test for canine parvovirus, Vet Microb, 41, 293-302.

5. Esfandiari J, Klingeborn B, 2000, A comparative study of a new rapid and one-step test for the detection of parvovirus in faeces from dogs, cats and mink, $J$ Vet Med. B, 47, 145-53.

6. Houston Doreen M, Ribble CS, Head LL, 1996, Risk factors associated with parvovirus enteritis in dogs: 283 cases (1982-1991), J Am Vet Med Ass, 208, 4, 542-6.

7. Kuffer Manuela, Hartmann Katrin, Kraft W, 1997, Canine parvovirose: Aspekte zu epidemiologie, klinik, laborbefunden, therapie und impfung, Tierarzt Prax, 25, 518-24.

8. Macartney L, McCandlish IAP, Thompson H, Cornwell HJC, 1984, Canine parvovirus enteritis 1: clinical, haematological and pathological features of experimental infection, Vet Rec, 115, 20110.

9. Mochizuki M, San Gabriel MC, Nakatani H, Yoshida M, 1993, Comparison of polymerase chain reaction with virus isolation and haemagglutination assays for the detection of canine parvoviruses in fecal specimens, Res Vet Sc, 55, 60-3.

10. O'Sullivan G, Durham PJK, Smith JR, Campbell RSF, 1984, Experimentally induced severe canine parvoviral enteritis, Austral Vet J, 61, 1, 1-4.

11. Oana L, Brudasca Florin, Timen Andrei, Miclaus Viorel, 2000, Changes in lymphoid tissues in parvoviral infections in dogs, Scientific proceedings, WSAVA-FECAVA world congress, Amsterdam, 176.

12. Sanekata T, Sugimoto T, Ueda S, Tsubokura M, Yamane Y, Senda M, 1996, Latex agglutination test for canine parvovirus, Austral Vet J, 73, 6, 215-7.

13. Trailović $D, 1999$, Gastroenterologija pasa i mačaka, etiopatogeneza, dijagnostika i terapija, Fakultet Veterinarske Medicine, Beograd, 126-8.

\section{METODE ZA DIJAGNOSTIKU PARVOVIROZE PASA}

\author{
SAVIĆ-JEVĐENIĆ SARA, TRAILOVIĆ D, VIDIĆ BRANKA i JOVANOVIĆ M
}

\section{SADRŽAJ}

Parvoviroza pasa je teško, kontagiozno oboljenje i javlja se u manjim ili većim enzootijama u čitavom svetu. Oboljevaju sve starosne kategorije pasa, ali prvenstveno štenad. lako su simptomi oboljenja veoma izraženi, tačna dijagnoza se ne može postaviti samo na osnovu kliničkog pregleda. Etiološka dijagnoza se bazira na dokazivanju virusa. U cilju ispitivanja vrednosti različitih laboratorijskih metoda za dijagnostiku parvovirusne infekcije pasa, eksperimentalno je izazvano oboljenje kod 12 štenadi. Posle pojave simptoma bolesti, psi su bili podvrgnuti 
Acta Veterinaria (Beograd), Vol. 56. No. 5-6, 515-527, 2006.

Savić-Jevđenić Sara et al.: Diagnostic methods

for canine parvovirus

svakodnevnoj kliničkoj opservaciji i vršeno je dokazivanje virusa u fecesu imunohromatografskom metodom, metodom hamaglutinacije i u crevnom epitelu metodom imunofluorescencije. Klinički oblik parvovirusne infekcije izazvan je i kod svih pasa koji su bili u kontaktu sa obolelom životinjom i sve obolele životinje su uginule (mortalitet 100\%). Kod obolelih pasa je uočena apatija, odsustvo apetita, povraćanje, dehidracija i registrovan je profuzan, hemoragičan proliv. Imunohromatografskom metodom i metodom hemaglutinacije, virus je dokazan u fecesu prvog dana nakon pojave kliničkih simptoma bolesti kod $100 \%$ obolelih pasa. Drugog dana metodom hemaglutinacije virus je dokazan kod $85 \%$ obolelih pasa, a imunohromatografskom metodom kod 53\% životinja. Pred uginuće, metodom hemaglutinacije virus je dokazan kod $61 \%$ pasa, a imunohromatografskom metodom samo kod $15 \%$ pasa. Metodom imunofluorescencije virus je dokazan u uzorcima tankog creva kod svih zaraženih pasa. 